\title{
Effect of Resected Gastric Fundus Fat on Ghrelin Tissue Levels: A Prospective Study
}

\author{
Ali Durmus', Ilgım Durmuș², Melis Abahuni², Oguzhan Karatepe ${ }^{3}$ \\ 'Department of Surgery, Nisantası University, Istanbul, Turkey \\ ${ }^{2}$ Genetics and Bioengineering, Istanbul, Turkey \\ ${ }^{3}$ Department of Surgery, Memorial Sisli Hospital, Istanbul, Turkey
}

Corresponding author:

Professor Oguzhan Karatepe General Surgery Clinic

Memorial Sisili Hospital, 34718, Istanbul-Turkey

E-mail: drkaratepe@yahoo.com

\section{Rezumat \\ Efectul rezectiei gastrice în regiunea fundică a stomacului asupra nivelului de gherlin: studiu prospectiv}

Introducere: Obezitatea este în prezent o problemă de sănătate importantă, care evoluează rapid la nivel mondial. În ultimii ani numărul intervențiilor chirurgicale conexe obezității a crescut. Cea mai frecventă preocedură chirurgicală a obezității este gastrectomia longitudinală laparoscopică (LSG). Scopul acestui studiu a fost compararea expresiei genetice a hormonului gherlin în zone diferite ale stomacului.

Material şi metodă: 19 pacienți obezi supuşi LSG au fost examinați în cadul acestui studiu. Grăsimea din două părți diferite ale stomacului (fundus şi zona superioara a acestuia) a fost analizată prin testul ELISA (enzyme-linked immunosorbent assay). Au fost aplicate tehnici de izolare ARN, ADN complementar şi RQ-PCR (detectie în timp real: real-time PCR). In plus, un kit de analiză ELISA a fost folosit pentru a măsura cantitatea de gherlin la pacienții obezi. $\mathrm{Au}$ fost comparate statistic nivelele de gherlin din fundus şi zona superioara a acestuia.

Rezultate: În cazul tuturor celor 19 pacienți, nivelul mediu de gherlin a fost mai mare de 30. Nivelul mediu de ghelin a stratului de grăsime localizat în partea superioara a fundusului a fost mai mare de 30 în cazul a 4 pacienți; nivelul mediu a fost 5 la restul pacienților. Am observat o diferență statistică semnificativă a nivelului de gherlin între fundus şi stratul de grăsime al acestuia.

Concluzie: Recoltarea țesutului gras din fundus nu este practicată de rutină în timpul LSG. Totuşi, creşterea nivelului de hormon gherlin în acest țesut necesită prelevarea de țesut din fundus în timpul intervenției chirurgicale.

Cuvinte cheie: gastrectomia longitudinală laparoscopică (LSG), nivel de gherlin, țesut gras gastric, fundus

\section{Abstract}

Introduction: Obesity is currently an important health problem that is rapidly 
increasing worldwide. In recent years, the number of obesity-related surgeries has increased. The most common type of obesity-related surgery is laparoscopic sleeve gastrectomy (LSG). The aim of this study was to compare the genetic expression of the hormone ghrelin in different parts of the stomach.

Materials and Methods: Nineteen obese patients who underwent LSG were examined in this study. Fat tissue from two different parts of the stomach, the fundus and the upper part of the fundus, were analysed by enzyme-linked immunosorbent assay (ELISA). The ribonucleic acid (RNA) isolation, complementary DNA (cDNA) and real-time quantitative polymerase chain reaction (RQ-PCR) techniques were applied. Additionally, a human ghrelin ELISA kit was used to measure ghrelin in obese patients. The ghrelin levels of fat tissue from the fundus and upper part of the fundus were statistically compared.

Results: In all 19 patients, the average ghrelin level in the fundus was greater than 30 . The average ghrelin level of the fat pad, which is located in the upper part of the fundus, was greater than 30 for 4 patients; the average level was approximately 5 in the remaining patients. A statistically significant difference in the ghrelin level was found between the fundus and the fundus fat tissue.

Conclusion: Collection of fundus fat tissue is not routinely performed during LSG. However, ghrelin hormone elevation in this tissue may require collection of fundus tissue during surgery.

Key words: laparoscopic sleeve gastrectomy, ghrelin level, gastric fat tissue, fundus

\section{Introduction}

In recent years, obesity has become an endemic disease that is rapidly increasing in our country and other countries. The World Health Organization defines obesity as an accumulation of fat that threatens overall health. The main causes of the increasing prevalence of obesity and overweight status are the consumption of high-energy nutrients and the reduction of the energy expended in the activities of daily life (1). Laparoscopic sleeve gastrectomy (LSG), which is a component of bariatric surgery, is a very popular option for the treatment of obesity (2). In this surgery, $3 / 4$ of the stomach is removed, and the stomach fundus, which has high ghrelin hormone levels, is collected. After LSG, the ghrelin concentration decreases (3-5).

Ghrelin is a metabolic stomach hormone. Ghrelin supports energy conservation during energy expenditure and regulation of the appetite. The ghrelin concentration affects body weight because it influences the appetite (6-8). It also regulates the distribution and rate of use of energy. The stomach is the principal ghrelin-secreting organ. Two other organs, thepancreas and hypothalamus, also produce ghrelin (9-11).

After LSG, $80 \%$ of patients exhibit effective weight loss. The most significant causes of weight loss are the reduction of gastric volume and the reduction of ghrelin hormone, which results in a reduced feeling of hunger in patients. Furthermore, the success of the diet applied after surgery is increased. However, weight loss is not effective in some patients whose diet remains the same and who experience the return of the feeling of hunger (12). In LSG, the stomach fundus is routinely removed, but the fundus and its surrounding tissue are not routinely removed. The aim of our study was to determine whether it is necessary to remove both the fat pad and fundus during LSG.

\section{Material and Methods}

This study was performed between September 2015 and August 2016. LSG surgery was performed by the same team for all patients. Tissue samples were collected from 19 obese patients. After the initial surgery, the laparoscopic surgical technique was performed. An average of 4 trocars were inserted into the abdomen, followed by $\mathrm{CO} 2$ infusion. The stomach was released along the large curvature, and then the fundus fat tissue was removed and sent for analysis. After the entire stomach was released, a 32 French tube was inserted from the mouth to the stomach. At one end of this tube, the stomach was attached to the tube using a stapler and then inserted into the fundus at a distance of 2 $\mathrm{cm}$ from the antrum. After the tape was removed, fundus samples were collected on the operating table and sent for evaluation.

\section{Genetic observation method}

Fundus and fundus fat tissue were obtained for examination. First, the trizol RNA isolation protocol was applied to both the fundus and fat pad of the obese patients. Then, optic density measurements were performed, and the cDNA protocol was applied. 


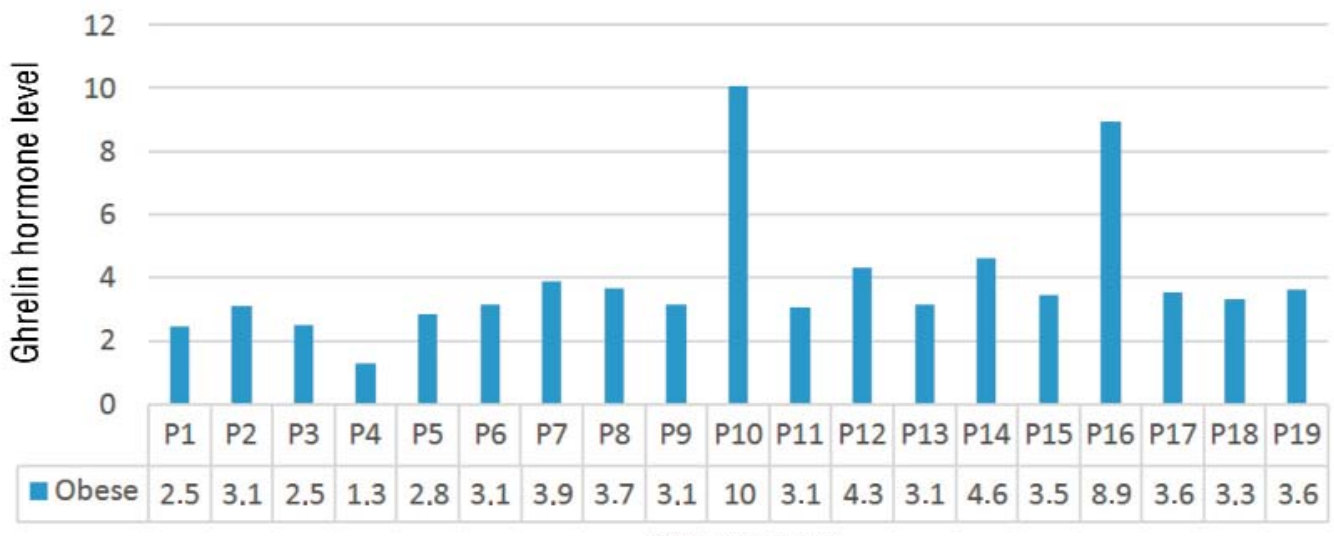

Patient Number

Figure 1. Ghrelin hormone levels in the blood of obese patients

Third, real-time quantitative polymerase chain reaction (RQ-PCR) was performed. Lastly, blood was collected from obese patients, and the ELISA protocol was applied.

\section{Results}

All blood ghrelin levels of the patients are shown in Fig. 1.
The average ghrelin level was 9 in the fundus fat tissue of the 19 patients included in this study. The ghrelin levels were considered high (the fat tissue level was 35 and the fundus level was 30) in the fundus of 4 patients. Fig. $2 A$ shows the fat pad ghrelin levels, and Fig. $2 B$ shows the average ghrelin level of the fundus.

As shown in Fig. $2 A$ and $2 B$, the average ghrelin expression level in the fat pad was 5.5492,
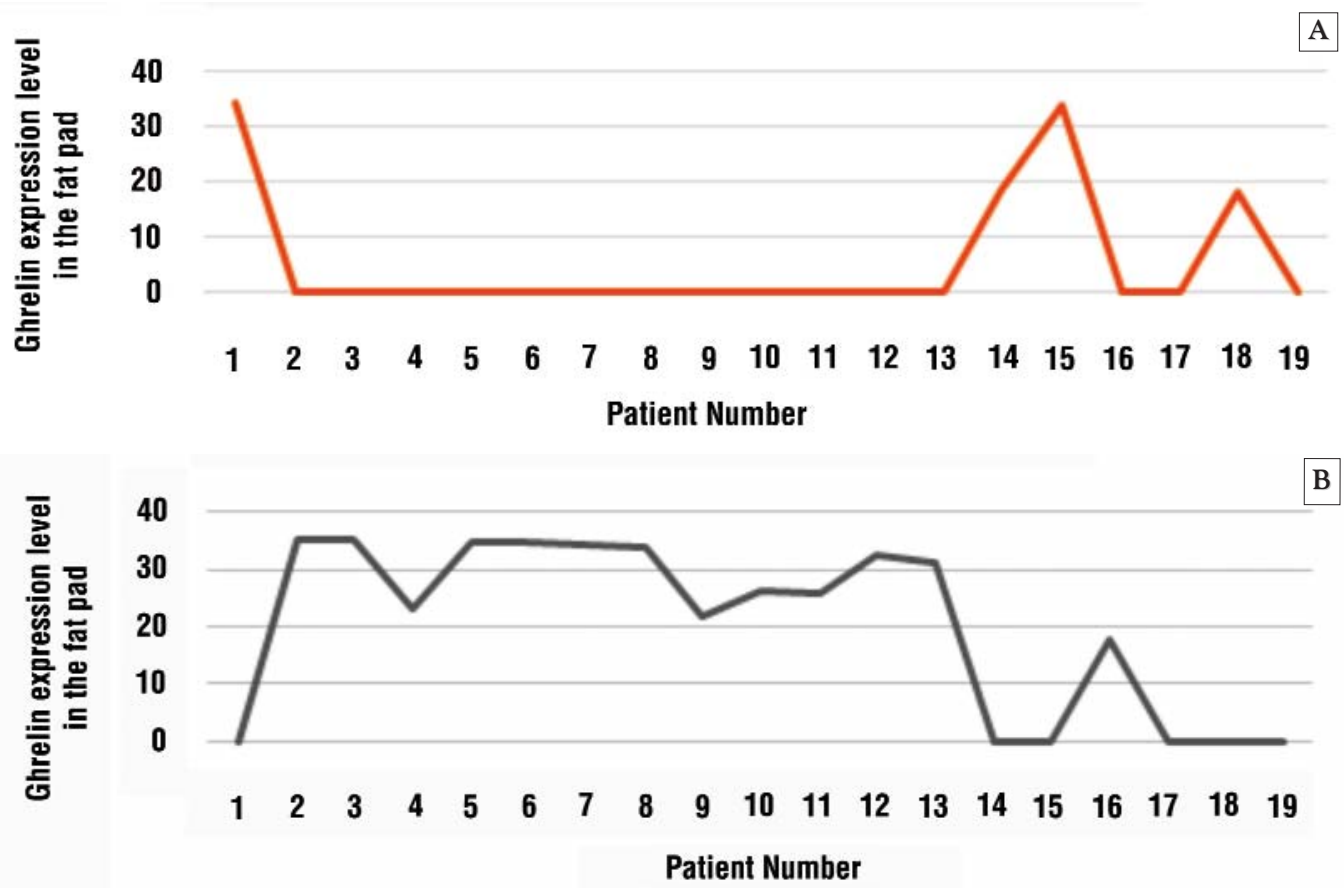

Figure 2. (A) Ghrelin expression levels in the fat pad; (B) Ghrelin expression levels in the fundus 


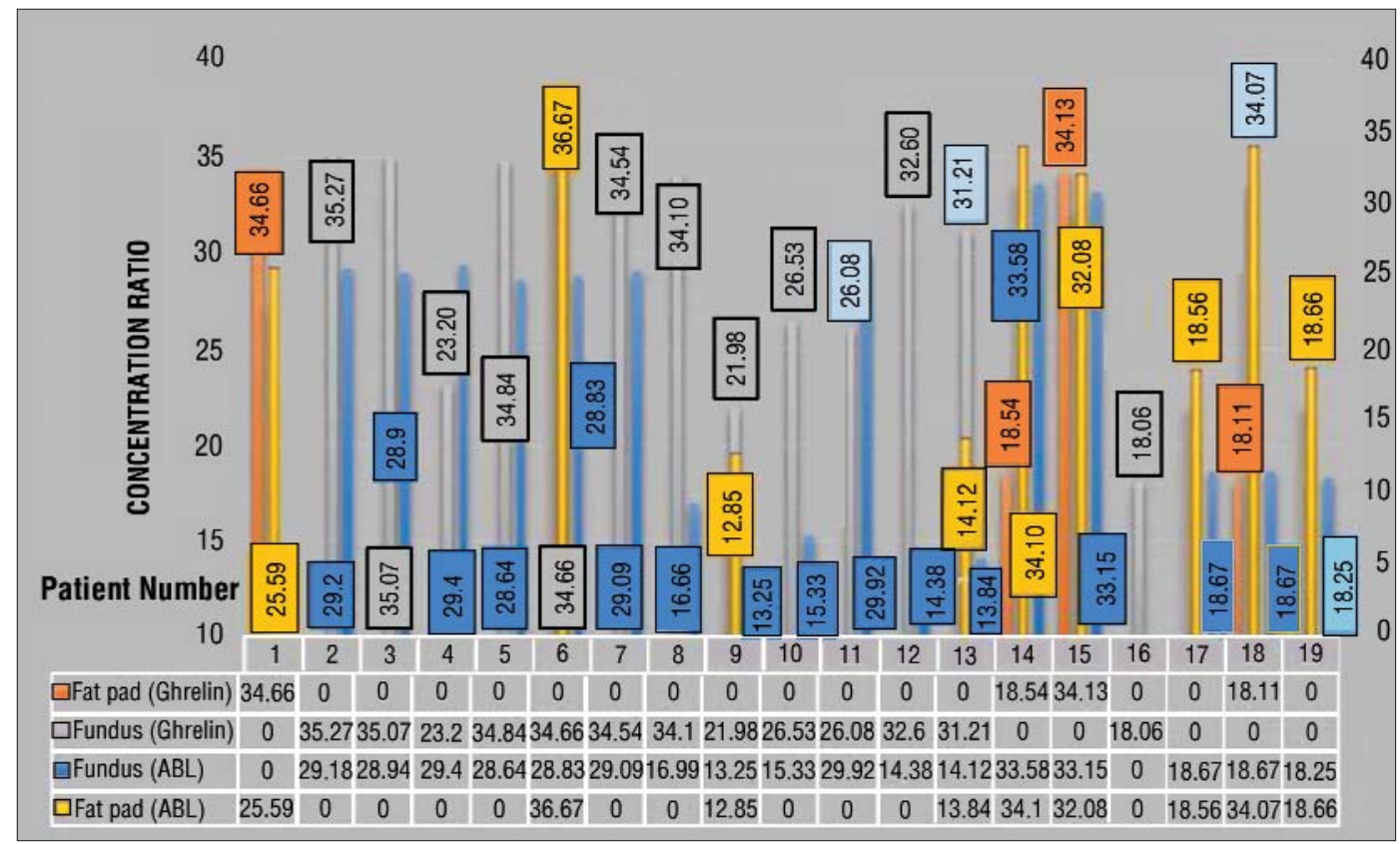

Figure 3. Comparison of the fundus and fat pad in obese patients. Fat pad and fundus samples were obtained from 19 obese patients. Ghrelin expression was measured in both the fat pad and fundus

and the average ghrelin expression level in the fundus was 19.1355. According to Fig. 1, 2A, and $2 B$, the ghrelin expression level in the fundus was higher than the ghrelin level of the fat pad.

When the ghrelin level of the fundus and fundus fat tissue were compared, the average fundus ghrelin level was significantly higherthan that of the fat tissue. Table 1 shows the comparison of the ghrelin levels of the fundus and fat tissue.

The other significant parameter in our study was the blood ghrelin level. These levels were compared before and after the operation. The ghrelin level in the postoperative period was significantly lower than that in the preoperative period in all patients.

The ghrelin levels measured by ELISA are shown in Fig. 3. Ghrelin hormone expression was found in the blood of obese patients.

\section{Discussion}

Ghrelin is a 28-amino acid peptide produced in the fundus of the stomach and the proximal intestine (12). Ghrelin is predominantly secreted by the gastric fundus and has various effects on food intake, such as increasing appetite and influencing chewing time, taste preferences, and food perception, as well as increasing gastrointestinal motility and decreasing insulin secretion. In non-obese individuals, ghrelin levels are highest immediately prior to a meal and decrease rapidly upon the initiation of food intake (13). Conversely, obesity is associated with reduced ghrelin levels, and food intake fails to modulate the levels of plasma ghrelin. Dietaryinduced weight loss is linked to increased ghrelin secretion, which has been postulated to contribute to the poor long-term success rates of dietary weight loss programmes by promoting increased food consumption, although this remains unproven $(12,13)$.

LSG involves the resection of the gastric fundus, and the procedure appears to permanently inhibit ghrelin production in most individuals within days of surgery. LSG is a relatively new bariatric operation that was designed as a restrictive procedure (14). The removed portion of the stomach, called the antrum, is also the part of the stomach that secretes many of the metabolically active gut hormones responsible for the neuro-hormonal response to food. Removing this portion can alter the body's biochemical response to food, changing appetite and food preferences. The fact that the fundus of the stomach, the main location of ghrelin-producing cells, is excluded in this procedure has led to speculation that ghrelin could play a role in the mechanism of actionof LSG. Three studies confirmed a decrease in fasting ghrelin levels after LSG $(13,15)$. A prospective, double-blind study comparing gastric bypass surgery and LSG confirmed a significant postprandial suppression of ghrelin postoperatively, while no change was observed in the gastric bypass group (16). In the same study, the marked suppres- 
sion of ghrelin levels after LSG was associated with greater appetite reduction and excess weight loss during the first postoperative year than for gastric bypass patients (16). A recent prospective randomized comparison of LSG and gastric bypass confirmed that both operations reduce fasting and mealstimulated ghrelin levels, with significantly greater reductions after LSG; therefore, the resection of the fundus has a greater effect on ghrelin levels than simply bypassing the fundus (13-15). In our study, obese patients underwent LSG, which exhibits low complication rates and good weight loss results. After the surgery, patients reported less hunger and started to lose weight successfully. Ghrelin, the "hunger hormone," signals the brain to eat. Our study shows that the ghrelin level is high not only in the fundus but also in the fundus fat pad. If the fat pad is not removed and the fundus is not sufficiently resected in the surgical procedure, the appetite will likely remain unchanged regardless of how small the stomach is, and patients will gain weight in the long term. One of the causes of weight gain is technical difficulty during the surgery. In such cases, the fundus is not sufficiently removed. However, if the fat pad and fundus are collected properly, after 2 years, the patient's appetite will remain the same, and the patient will start to gain weight (17). If patients do not regularly control themselves, pay attention their diet (nutrition, weight, and protein), and exercise sufficiently, weight loss will stop. The main aim during the 2 years following surgery is to encourage proper habits $(18,19)$. From a technical aspect, the fat pad and fundus should be collected.

After LSG, some patients regain weight and feel hungry. Weight loss is not sufficient in these patients after surgery. Few studies have addressed this subject. However, according to the literature (17-19), the major reason for regaining weight is that patients do not adhere to their diet or sufficiently alter their lifestyle.

One study asked patients to describe the most important problem in their diet, and the answer was the feeling of hunger (24). The feeling of hunger is an important problem to reconcile. Although different organs secrete ghrelin, the stomach fundus secretes the highest level. In our study, the ghrelin level was found to be high in the fat pad of the fundus, which is not routinely included in LSG, even though we showed that the ghrelin level of the fat pad was higher than the ghrelin level of the fundus in 4 patients. Thus, our study is a pilot study, and it remains to be determined whether regaining weight and the feeling of hunger are related to ghrelin levels.
We observed that the ghrelin gene plays a significant role in obesity because ghrelin promotes energy conservation due to energy expenditure and regulation of the appetite. LSG is an important obesity treatment that is effective in the short term and has exhibited growing popularity. The superior clinical results of surgery have focused attention on the option of partial gastric resection and the possible effects of mediators released from the resected portion. The role of the ghrelin hormone in the development of morbid obesity is not yet known. However, we believe that the ghrelin-producing fundus area should be removed during surgery and that ghrelin is a hormone that is closely linked to obesity due to the marked loss in appetite during the period immediately following obesity surgery. In addition, our study shows that the fundus fat tissue should be routinely removed during LSG. Further studies on this subject are necessary.

\section{References}

1. Caballero B. A nutrition paradox - underweight and obesity in developing countries. N Engl J Med. 2005;352(15):1514-6.

2. Buchwald H, Oien DM. Metabolic/bariatric surgery Worldwide 2008. Obes Surg. 2009;19(12):1605-11. doi: 10.1007/s11695-009-0014-5.

3. Langer FB, Reza Hoda MA, Bohdjalian A, Felberbauer FX, Zacherl J, Wenzl $E$, et al. Sleeve gastrectomy and gastric banding: effects on plasma ghrelin levels. Obes Surg. 2005;15(7):1024-9.

4. Karamanakos SN, Vagenas K, Kalfarentzos F, Alexandrides TK. Weight loss, appetite suppression, and changes in fasting and postprandial ghrelin and peptide-YY levels after RouX-en- $Y$ gastric bypass and sleeve gastrectomy: a prospective, double blind study. Ann Surg. 2008;247(3):401-7. doi: 10.1097/SLA.0b013e318156f012.

5. Paspala I, Katsiki N, Kapoukranidou D, Mikhailidis DP, TsiligiroglouFachantidou A. The role of psychobiological and neuroendocrine mechanisms in appetite regulation and obesity. Open Cardiovasc Med J. 2012;6:147-55. doi: 10.2174/1874192401206010147.

6. Date Y, Nakazato M, Hashiguchi S, Dezaki K, Mondal MS, Hosoda $\mathrm{H}$, et al. Ghrelin is present in pancreatic alphacells of humans and rats and stimulates insulin secretion. Diabetes. 2002;51(1):124-9.

7. Sato T, Fukue Y, Teranishi H, Yoshida Y, Kojima M. Molecular forms of hypothalamic ghrelin and its regulation by fasting and 2-deoxy-dglucose administration. Endocrinology. 2005;146(6):2510-6.

8. Jones-Smith JC, Gordon-Larsen P, Siddiqi A, Popkin BM. Crossnational comparisons of time trends in overweight inequality by socioeconomic status among women using repeated crosssectional surveys from 37 developing countries, 1989-2007. Am J Epidemiol. 2011;173(6):667-75. doi: 10.1093/aje/kwq428.

9. Kojima M, Hosoda H, Date $Y$, Nakazato M, Matsuo $H$, Kangawa K. Ghrelin is a growth-hormone-releasing acylated peptide from stomach. Nature. 1999;402(6762):656-60.

10. Jones-Smith JC, Gordon-Larsen P, Siddiqi A, Popkin BM. Emerging disparities in overweight by educational attainment in Chinese adults (1989-2006). Int J Obes (Lond). 2012;36(6):866-75. doi: 10.1038/ijo.2011.134. Epub 2011 Jul 5.

11. Liou JM, Lin JT, Lee WJ, Wang HP, Lee YC, Chiu HM, et al. The serial changes of ghrelin and leptin levels and their relations to weight loss after laparoscopic minigastric bypass surgery. Obes Surg. 2008;18(1):84-9. Epub 2007 Dec 15.

12. Garcia Ulen C, Huizinga MM, Beech B, Elasy TA. Weight regain prevention. Clinical Diabetes 2008;26(3):100-113. doi: 10.2337 
/diaclin.26.3.100

13. Melissas J, Daskalakis M, Koukouraki S, Askoxylakis I, Metaxari M, Dimitriadis E, et al. Sleeve gastrectomy-a "food limiting" operation. Obes Surg. 2008;18(10):1251-6. doi: 10.1007/s11695-008-9634-4.

14. Bernstine H, Tzioni-Yehoshua R, Groshar D, Beglaibter N, Shikora $\mathrm{S}$, Rosenthal RJ, et al. Gastric emptying is not affected by sleeve gastrectomy--scintigraphic evaluation of gastric emptying after sleeve gastrectomy without removal of the gastric antrum. Obes Surg. 2009; 19(3):293-8. doi: 10.1007/s11695-008-9791-5. Epub 2008 Dec 17.

15. Cohen R, Uzzan B, Bihan H, Khochtali I, Reach G, Catheline JM. Ghrelin levels and sleeve gastrectomy in super-super-obesity. Obes Surg. 2005;15(10):1501-2.

16. Karamanakos SN, Vagenas K, Kalfarentzos F, Alexandrides TK. Weight loss, appetite suppression, and changes in fasting and postprandial ghrelin and peptide-YY levels after Roux-en-Y gastric bypass and sleeve gastrectomy: a prospective, double blind study. Ann Surg. 2008;247(3):401-7. doi: 10.1097/SLA.0b013e318156f012.

17. Wilson EB. The evolution of robotic general surgery. Scand J Surg. 2009;98(2):125-9

18. Ayloo S, Buchs NC, Addeo P, Bianco FM, Giulianotti PC. Robot- assisted sleeve gastrectomy for super-morbidly obese patients. J Laparoendosc Adv Surg Tech A. 2011;21(4):295-9. doi: 10.1089/ lap.2010.0398.

19. Edelson PK, Dumon KR, Sonnad SS, Shafi BM, Williams NN. Robotic vs. conventional laparoscopic gastric banding: a comparison of 407 cases. Surg Endosc. 2011;25(5):1402-8. doi: 10.1007/s00464-0101403-5. Epub 2010 Oct 26.

20. Kiriakopoulos A, Varonuis C, Tsakayannis D, Linos D. Laparoscopic sleeve gastrectomy in morbidly obese patients. Technique and short term result. Hormones (Athens). 2009;8(2):138-43.

21. Lauti M, Kularatna M, Hill AG, MacCormick AD. Weight Regain Following Sleeve Gastrectomy-a Systematic Review. Obes Surg. 2016 26(6):1326-34. doi: 10.1007/s11695-016-2152-x.

22. Egberts K, Brown WA, Brennan L, O'Brien PE. Does exercise improve weight loss after bariatric surgery? A systematic review. Obes Surg. 2012;22(2):335-41. doi: 10.1007/s11695-011-0544-5.

23. Silver HJ, Torquati A, Jensen GL, Richards WO. Weight, dietary and physical activity behaviors two years after gastric bypass. Obes Surg. 2006;16(7):859-64.

24. Pournaras DJ, le Roux CW. Ghrelin and metabolic surgery. Int J Pept. 2010;2010. pii: 217267. doi: 10.1155/2010/217267. 